\title{
INFLUENCE OF DIFFERENT CASTING CONDITIONS AND THE FILTERING PROCESS ON THE ELECTRICAL RESISTANCE OF Al-ALLOY 99.7
}

\author{
VPLIV RAZLIČNIH POGOJEV LITJA IN PROCESA FILTRIRANJA \\ NA ELEKTRIČNO UPORNOST Al-ZLITINE 99.7
}

\author{
Terezija Poženel Kovačič́1, Mitja Petrič², Vitoslav Bratušr ${ }^{1}$, Maja Vončina ${ }^{2}$ \\ ${ }^{1}$ Hidria Rotomatika d.o.o., Spodnja Kanomlja 23, 5281 Spodnja Idrija, Slovenia
${ }^{2}$ Faculty for Natural Sciences and Engineering, Department of Materials and Metallurgy, Aškerčeva 12, 1000 Ljubljana, Slovenia \\ terezija.kovacic@hidria.com \\ Prejem rokopisa - received: 2017-07-22; sprejem za objavo - accepted for publication: 2018-01-24
}

doi:10.17222/mit.2017.123

\begin{abstract}
There are different types of electric motors; one of them is the induction motor. Such a motor consists of a winded stator and an induction rotor. The rotor squirrel cage is made with aluminium high-pressure die casting technology. Besides relatively low motor-producing costs and good repeatability, the motor efficiency and torque/speed characteristics are also important. One of the loss factors for the rotor is the loss of conductance of die cast material. This study researches how different casting conditions influence the material's electrical resistivity of Al 99.7. With melting of the alloy in an induction vacuum furnace and testing various casting conditions during the solidification (such as the vacuum, air and filtering), the temperature and electrical resistivity of the castings were measured using the four-point measuring method. The porosity proportions of the samples were examined with X-ray, as well as with optical microscopy. The presence of Fe-eutectic $\left(\alpha-\mathrm{Al}+\mathrm{Al}_{13} \mathrm{Fe}_{4}\right)$ was confirmed in the investigated samples' microstructures, as was predicted by a calculation of the equilibrium phase diagram. The electrical resistivity values were additionally measured with an eddy-current measuring method. The results show a good correlation with the four-point measuring method and are in a range $29-33 \mathrm{n} \Omega \mathrm{m}$ at $20{ }^{\circ} \mathrm{C}$. Based on the obtained results, the influence of impurities and porosity on the electrical properties of aluminium was evaluated.

Keywords: electrical resistivity, impurities, porosity, casting conditions
\end{abstract}

Obstajajo različni tipi električnih motorjev in eden izmed njih je tudi indukcijski motor. Indukcijski motor je sestavljen iz navitega statorja in indukcijskega rotorja. Prevodna kratkostična kletka indukcijskega rotorja je lahko narejena s postopkom visokotlačnega litja aluminija. Poleg relativno nizkih stroškov izdelave sta zelo pomembni učinkovitost in karakteristika (navor/hitrost) takega električnega motorja. K skupnim izgubam motorja prištevamo tudi izgubo prevodniškega materiala kratkostične kletke rotorja. Cilj raziskave je ugotoviti, kako pogoji litja vplivajo na električno prevodnost litega materiala Al 99.7. Taljenje in gravitacijsko litje zlitine je potekalo v indukcijski vakuumski peči pri različnih pogojih strjevanja (vakuum, zrak in filtriranje s penjenimi keramičnimi filtri). Med strjevanjem ulitka smo spremljali temperaturo in merili električno upornost vzorca s štiritočkovno merilno metodo. Delež poroznosti je bil analiziran z rentgenom in tudi z optično mikroskopijo. Prisotnost $\left(\alpha-\mathrm{Al}+\mathrm{Al}_{13} \mathrm{Fe}_{4}\right)$ evtektika je bila potrjena tako, kot je predvidel predhodni termodinamični izračun. Dodatno smo električno upornost vzorcev merili še z merilno metodo vrtinčnih tokov. Rezultati so primerljivi ter so v območju $29-30 \mathrm{n} \Omega \mathrm{m}$ pri $20{ }^{\circ} \mathrm{C}$. Na podlagi pridobljenih rezultatov smo ocenili vpliv nečistoč in poroznosti na električne lastnosti aluminija.

Ključne besede: električna upornost, nečistoče, poroznost, pogoji litja

\section{INTRODUCTION}

Aluminium is the most common choice for a rotor conductance material due to its good ratio between conductivity, weight, price and technology parameters. Commercially pure aluminium from $1 \mathrm{xxx}$ series is the most common, with varying degrees of purity: (99.0, 99.5 or 99.7$) \%$ of mass fractions. Such aluminium typically achieves up to $60 \%$ IACS (International Annealed Copper Standard). For the induction motor, the electrical conductivity of the cast material is important to reduce the current losses in the rotor cage. ${ }^{1-5}$

Commercially pure aluminium contains from $0.3 \%$ to $1.0 \%$ of mass fractions of impurities, mainly iron and silicon. The typical amount of iron in the primary aluminium is between 0.03 and $0.15 \%$ of mass fractions. The equilibrium concentration of iron dissolved in the liquid phase of the aluminium is up to $2.5 \%$ of mass fractions at $700{ }^{\circ} \mathrm{C}$. Iron has a high solubility in liquid aluminium, while the solubility is greatly reduced in the solid ( $0.05 \%$ of mass fractions at room temperature). During solidification $\left(\alpha-\mathrm{Al}+\mathrm{Al}_{13} \mathrm{Fe}_{4}\right)$ the eutectic is formed at lower temperature. ${ }^{6,7}$ Non-metallic inclusions present in the castings, most commonly $\mathrm{Al}_{2} \mathrm{O}_{3}$ particles, are a result of the oxidation process. Inclusions, like impurities, enter the system as a side product of the melting and die-casting process. ${ }^{8,9}$ Porosity is one additional factor that deteriorates the electrical and mechanical properties of aluminium. ${ }^{10,11}$

Electrical conductivity is very sensitive to the composition, crystalline states and processing conditions of metallic materials since it is determined by the scattering of electrons due to disturbances in the atomic crystal structure. This is according to the Bloch theorem, 
where defects in the crystal lattice (vacancies, foreign atoms and thermal fluctuation) represent the scattering of electrons. The scattering of electrons is evaluated by the specific resistance $(\rho)$ of the metal, which is the inverse of the specific electrical conductivity $(\sigma) .^{12}$

The most important influential factors on the electrical conductivity are the chemical composition, and the amount of $\mathrm{Fe}$ and transition-metal (TM) elements. $1 \mathrm{xxx}$ series alloys have a narrow specification range of dissolved impurities allowing especially transition metals (V, Ti, Zr, and $\mathrm{Cr}<0.03 \%$ of mass fractions). There are two main reasons: the first is that the TM elements prefer to stay dissolved in the Al matrix, causing lattice distortion. The second reason is that TM elements, such as $\mathrm{Ti}$ and $\mathrm{V}$, are active in $\mathrm{Al}$ melts and they easily react with Al forming TM/Al compounds. These reactions reduce the number of free electrons, which are determining the electrical conductivity values. ${ }^{13-15}$

Most available researches of electrical resistivity are based on aluminium alloys with silicon, ${ }^{16-18}$ which are widely applied in the industry for high-pressure die casting. While the alloys from the group 1 xxx are very rarely involved in the research of die casting processes. The 1xxx series is better represented in an area of electrical energy transmission inside the energy sector.

The investigation presented in the description of the results and subsequent discussion with the conclusions given in Section 4, shows how impurities, porosity and different casting conditions are influencing the electrical resistivity of cast material Al 99.7 measured with two different measuring methods.

\section{EXPERIMENTAL PART}

With the aim of monitoring the electrical conductivity variation during the solidification, analyses of the solidification and cooling were performed in a laboratory
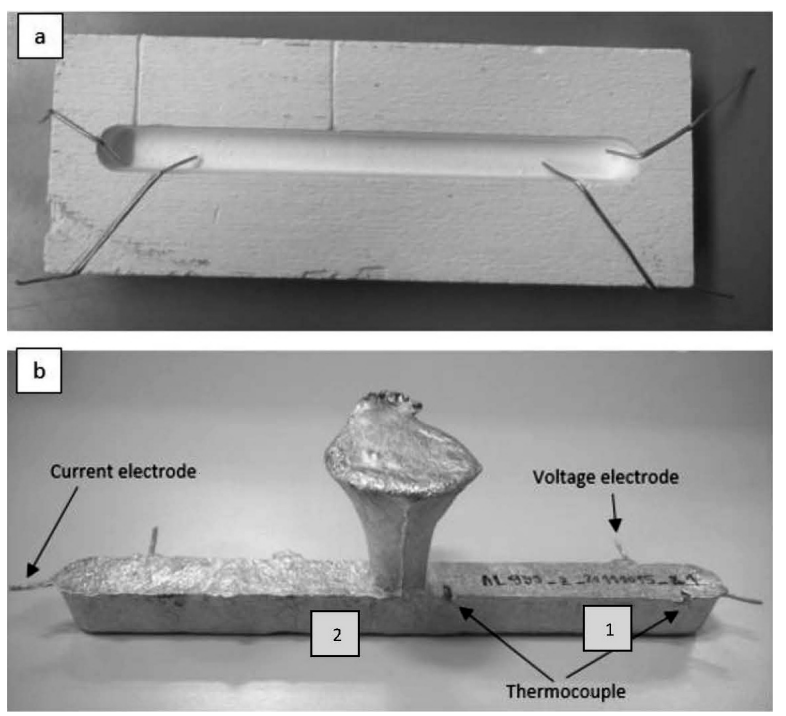

Figure 1: Calcium silicate measuring cell: a) casting from the measuring cell with marked positions of thermocouples and b) electrodes with a custom-made device. In situ-measuring device simultaneously measures the change in temperature and the change in the electrical resistivity of the cast part. The measuring cell built using the principle of the fourpoint measuring method allows measuring of voltage when passing a known quantity of electric current through the known cross-section and length of the casting (Figure 1a). The measuring cell has two type-K thermocouples for temperature measuring. Measuring data was collected with a frequency of $10 \mathrm{~Hz}$ using a National Instruments measuring card connected to the computer. The data obtained were processed with the software package Origin 9.0.

The casting is $210 \mathrm{~mm}$ long and has a trapezoid cross section with a surface of $294 \mathrm{~mm}^{2}$ (Figure 1b). The melt was poured into the casting cavity through a centrally positioned funnel-shaped gating system where also $\mathrm{Al}_{2} \mathrm{O}_{3}$ ceramic foam filter could be placed, if needed. The measuring cell is made from fire-resistant material based on calcium silicate. ${ }^{19,20}$

Several experimental samples were obtained. Melting, casting and measuring were done in an induction vacuum heating furnace which allows heating up to $2000{ }^{\circ} \mathrm{C}$ and can reach a vacuum pressure of $10^{-3}$ mbar. The same input melting material Al 99.7 was used for all the samples. The chemical composition of material according to EN 576 standard is given in Table 1. For casting in Ar the chamber was sealed and evacuated to achieve a vacuum of 0.3 mbar. After that the $\mathrm{Al} 99.7$ was melted in vacuum. Before the gravity casting was done, the furnace chamber was filled with Ar. Samples obtained by the process described above were marked with the suffix _Ar. For the samples cast in air, the chamber was opened and the procedure was repeated in an air atmosphere. These samples are marked with the suffix _z. Additionally, ceramic foam filters were used during the predicted experiments when casting in air to see whether filtering has significant impact on the solidified structures and the electrical conductivity. These samples have a prefix $\mathrm{F}$ in this article.

Table 1: Chemical composition of initial material and investigated samples, in mass fractions $(w / \%)$

\begin{tabular}{|c|c|c|c|c|}
\hline \multirow{2}{*}{ Sample name } & \multicolumn{4}{|c|}{ Element $(w / \%)$} \\
\cline { 2 - 5 } & $\mathrm{Al}$ & $\mathrm{Si}$ & $\mathrm{Fe}$ & Rest. \\
\hline $\begin{array}{c}\text { material acc. to EN 576 } \\
\text { standard used in research }\end{array}$ & 99.760 & 0.040 & 0.160 & 0.041 \\
\hline 997_z & 99.731 & 0.040 & 0.178 & 0.051 \\
\hline F997_z & 99.744 & 0.045 & 0.188 & 0.023 \\
\hline 997_Ar & 99.740 & 0.051 & 0.187 & 0.022 \\
\hline
\end{tabular}

Cast samples were first examined by X-ray Gilardoni $160 \mathrm{kV}$ to get an insight in porosity levels. For a more accurate analysis, samples were later on cut into smaller pieces. The chemical composition of the castings was obtained using optical emission spectroscopy ARL 3460 machine. Metallographic samples were prepared at the cross-sections made at both thermocouples, as seen in 
Figure 1b. They were prepared according to a standard metallographic procedure for cast aluminium alloys with different grinding and polishing steps. Furthermore, the TCW5 ThermoCalc program with the TCAL4 database was used to calculate the thermodynamic equilibrium solidification and to predict the equilibrium phase formation. Measurements of the electrical conductivity were performed on the samples used for metallographic investigations with the Autosigma 3000 probe machine according to the IACS standard. Finally, a Olympus BX51M optical microscope and JEOL JMS-5610 electron microscope equipped with an EDS micro analyser were used in order to do the microstructure analysis of the experimental samples.

\section{RESULTS AND DISCUSSION}

Chemical composition is the basis for the calculation of equilibrium phase diagram and the expected equilibrium proportion of phases, which can be found in the
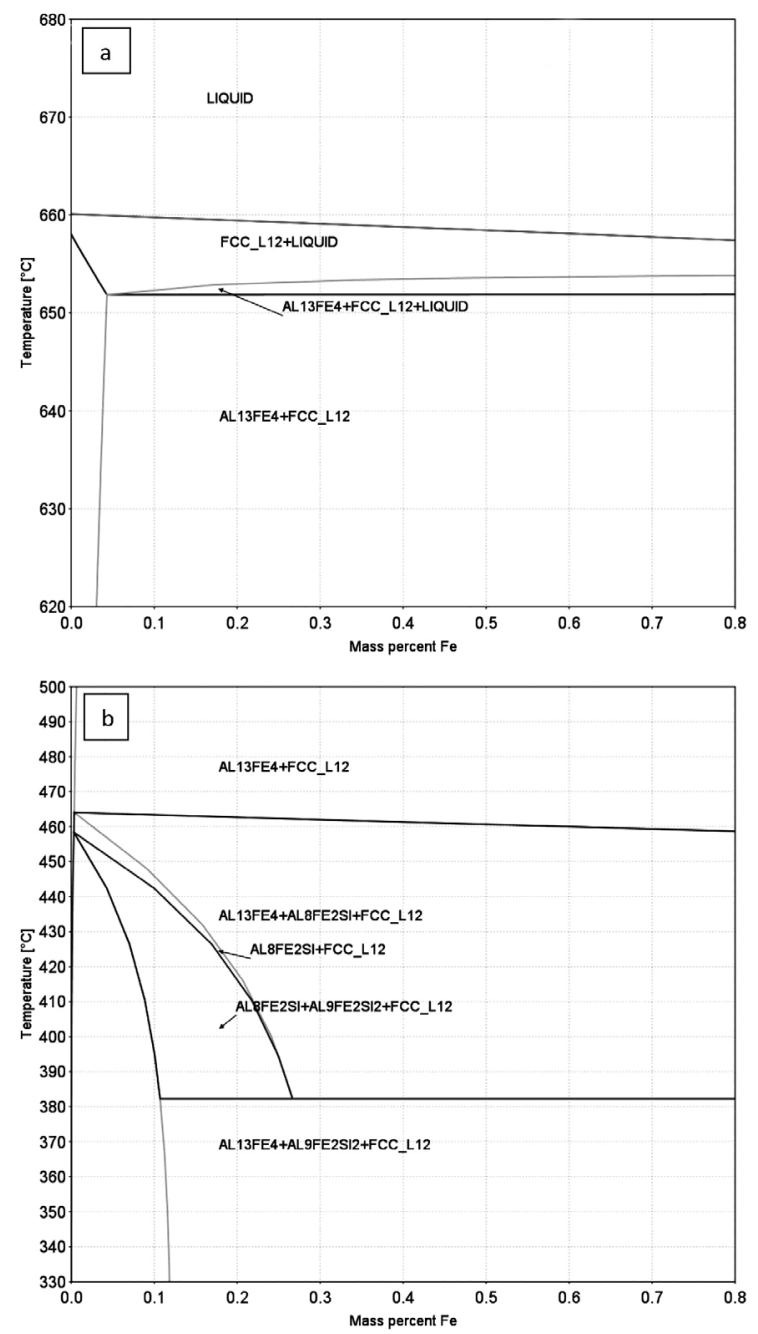

Figure 2: Isoplete equilibrium phase diagrams calculated from the chemical composition of cast sample $997 \_\mathrm{z}$ at $0.178 w / \% \mathrm{Fe}$ and $0.040 \mathrm{w} / \% \mathrm{Si}$, solidification at: a) higher temperatures and b) at lower temperatures investigated alloys at room temperature. Equilibrium solidification for Al 99.7 is as follows (Figure 2): as the first primary crystals $\alpha$-Al at the temperature $659.6{ }^{\circ} \mathrm{C}$ solidify, followed by the solidification of eutectic $(\alpha-\mathrm{Al}$ $\left.+\mathrm{Al}_{13} \mathrm{Fe}_{4}\right)$ at $653.2{ }^{\circ} \mathrm{C}$, the solidus temperature is at $652.8^{\circ} \mathrm{C}$. At a temperature of $284.9^{\circ} \mathrm{C}$, the precipitation of $\mathrm{Al}_{9} \mathrm{Fe}_{2} \mathrm{Si}_{2}$ phase from the solid solution occurs, the proportion of which is very small relative to the composition under investigation. The calculated proportion of eutectic phase $\mathrm{Al}_{13} \mathrm{Fe}_{4}$ is $0.32 \%$ for $997 \_\mathrm{z}$ alloy.

Using simple thermal analysis the comparison of the solidification curves of the same alloy type with different casting conditions was made. Commercially pure aluminium 99.7 is solidified under practically isothermal conditions at temperatures around $657.5{ }^{\circ} \mathrm{C}$ (Figure 3), similar as the ThermoCalc calculation predicted. Due to the non-equilibrium conditions, for instance higher cooling rate $\left(1.2^{\circ} \mathrm{C} / \mathrm{s}\right)$, the solidification temperatures move to lower values. The liquidus temperature is higher for the samples cast in air and for the samples cast with a filter in comparison to the samples cast in Ar. For the primary solidification range recalescence can be observed, which is the driving force for crystal nuclei formation. Later on, the iron phase in the form of eutectic reaction $\left(\alpha-\mathrm{Al}+\mathrm{Al}_{13} \mathrm{Fe}_{4}\right)$ is solidified. It was found that the casting conditions do not influence the temperature of the eutectic solidification. The eutectic forms at $644{ }^{\circ} \mathrm{C}$ and it is consistent with all the experimentally obtained samples.

Along with the temperature change, the change in electrical resistivity was measured. Measurements of the specific electrical resistivity of the investigated samples are shown in Figure 4. The electrical resistivity $\rho$ values at the casting temperatures are approximately $245.8 \mathrm{n} \Omega \mathrm{m}$ and are changing linearly till the $T_{\mathrm{L}}$ point, where the drop is significant. After $T_{\mathrm{s}}$, the electrical resistivity is again changing linearly with time and at $20{ }^{\circ} \mathrm{C}$ reaches the values around $30 \mathrm{n} \Omega \mathrm{m}$.

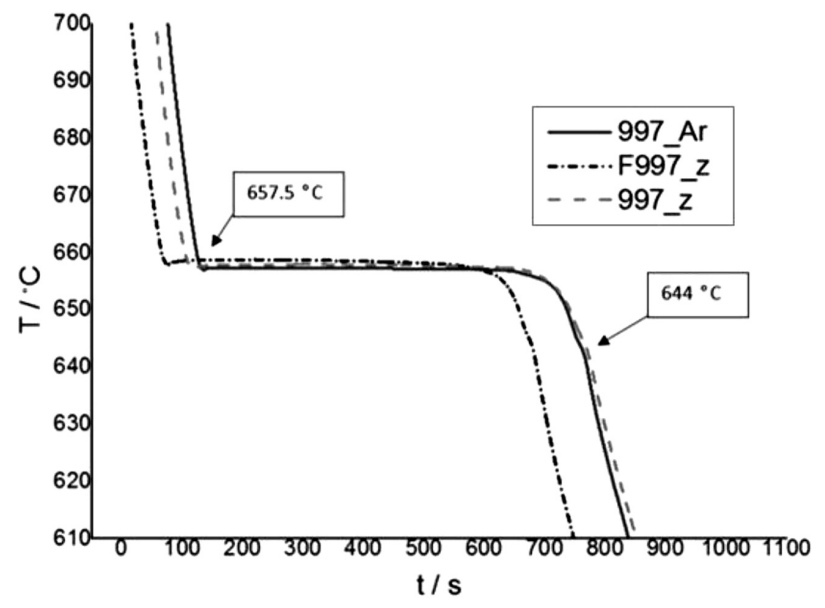

Figure 3: Cooling curve of three experimental samples Al 99.7 with different casting and cooling conditions; temperature marks for the liquidus and the eutectic reaction are shown 


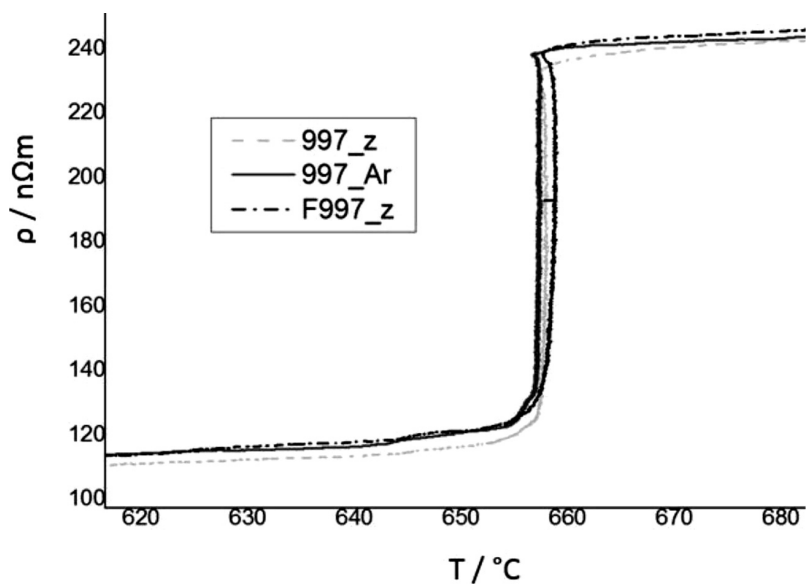

Figure 4: Specific electric resistivity in correlation to the temperature made for all samples

The microstructure from the site of thermocouple 1 (Figure 1b) confirms the proportion of $\mathrm{Fe}$ and the resulting Fe-eutectic $\left(\alpha-\mathrm{Al}+\mathrm{Al}_{13} \mathrm{Fe}_{4}\right)$ in the investigated samples (Figure 5).

In Figure 4 the relations between the measured electrical resistivity $\rho$ for all the investigated samples can be observed. The electrical resistivity $\rho$ of sample $997 \_z$ is lower in comparison to the other two samples. This is not consistent with the literature, but can be attributed to the percentage of Fe content, which is lower in this sample (Table 1). As described in the literature ${ }^{14,15}$ the primary influence on the electrical properties can be connected to the chemical composition. This is also supported by Equation (1), which describes the electrical resistivity $\rho$ for resistors that have a uniform cross-section $A$ with a uniform flow of electric current on length $l$, and are made of one material with the electrical resistance value $R$ :

$$
\rho=R \frac{A}{l}
$$

The cross-sections of all the samples for both thermocouple positions were measured. It was determined that the 997_Ar sample areas were about $6 \%$ bigger in

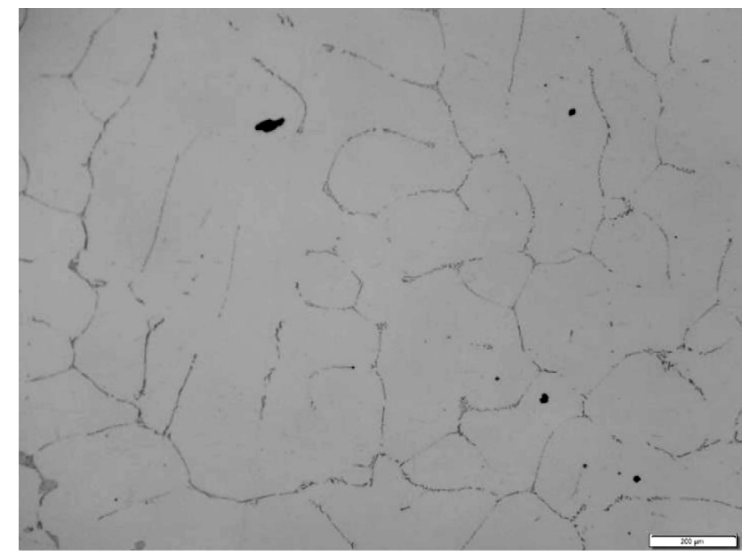

Figure 5: Microstructure of the cross-section area 1 for the sample cast in air comparison with cross-sections of samples 997_z and F997_z. This result also in a larger electrical resistivity $\rho$ for the 997_Ar obtained with the four-point measuring method, as shown in Table 2.

Table 2: Electrical conductivity values obtained with the eddy-current measuring method (Autosigma 3000), measured at $20{ }^{\circ} \mathrm{C}$ with added four-point measuring method resistivity values

\begin{tabular}{|c|c|c|c|}
\hline & \multicolumn{2}{|c|}{$\begin{array}{c}\text { Eddy-current } \\
\text { measuring method }\end{array}$} & $\begin{array}{c}\text { Four-point } \\
\text { measuring } \\
\text { method } \\
\text { (extrapolation) }\end{array}$ \\
\hline $\begin{array}{c}\text { Sample } \\
\text { name }\end{array}$ & $\begin{array}{c}\text { Electrical con- } \\
\text { ductivity } \\
\text { (\% IACS) }\end{array}$ & $\begin{array}{c}\text { Electrical resis- } \\
\text { tivity }(\mathrm{n} \Omega \mathrm{m}) \text { at } \\
20^{\circ} \mathrm{C}\end{array}$ & $\begin{array}{c}\text { Electrical resis- } \\
\text { tivity }(\mathrm{n} \Omega \mathrm{m}) \text { at } \\
20^{\circ} \mathrm{C}\end{array}$ \\
\hline 997_z & 58.72 & 29.41 & 31.52 \\
\hline $997 \_A r$ & 59.23 & 29.15 & 33.08 \\
\hline F997_z & 57.30 & 30.09 & 31.53 \\
\hline
\end{tabular}

The evaluated porosity on the sample's cross-section area 1 is $0.51 \%$ for $997 \_z$ sample and $0.39 \%$ for sample 997_Ar. Casting over the filter has no impact on the porosity decrease, and the electrical resistivity values were not reduced either. This was confirmed by the $\mathrm{X}$-ray analysis of the samples shown in Figure $\mathbf{6}$ as well.

The electrical conductivity according to the IACS standard for the investigated samples was also analysed using special probe machine Autosigma 3000 Eddy Current Tester. The eddy current measurement of the electrical conductivity is essentially a "skin" effect measurement. The eddy-current field intensity is the greatest at the surface and decreases exponentially with depth; therefore, the sample thickness must be large enough. Furthermore, the surface characteristics are also important, whereas possible surface inhomogeneities, such as porosity, affect the measurements. The sample surfaces were therefore grinded and prepared prior to

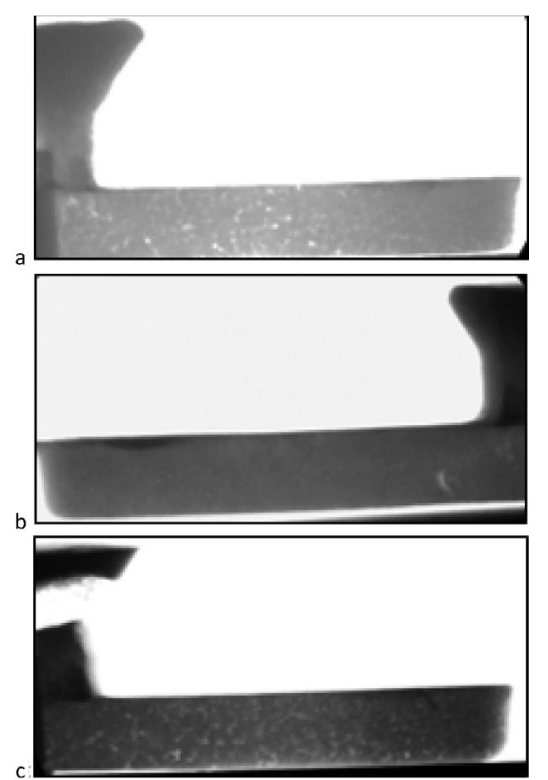

Figure 6: X-ray images of: a) sample 997_z, b) sample 997_Ar and c) sample F997_z 

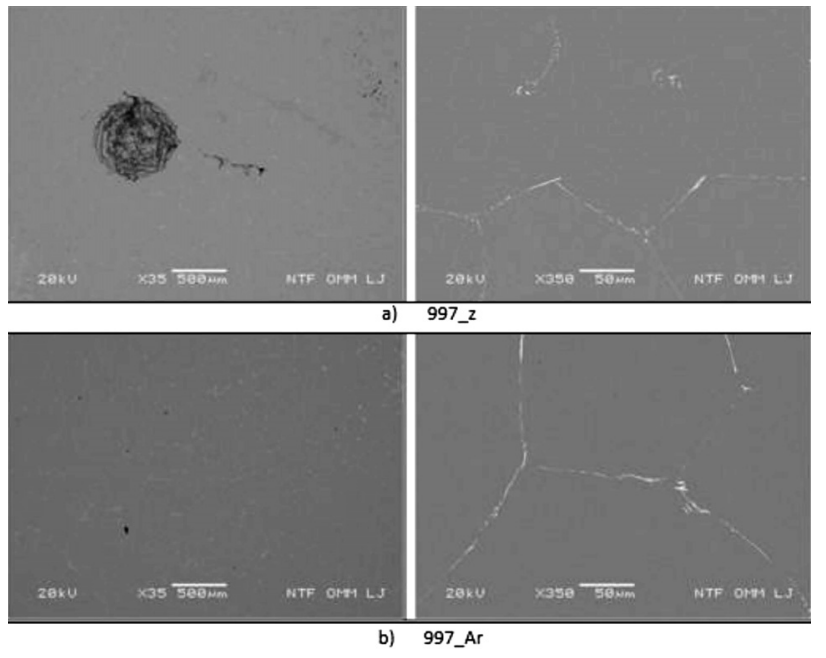

Figure 7: SEM microphotograph for: a) 997_z and b) 997_Ar

measurement. The testing results are summarized in Table 2.

Five measurements were made on each sample cross-section and their average was calculated. The obtained data is in good agreement with, ${ }^{4,5}$ where for Al-alloy 99.7 the electrical conductivity is stated in a range of 57-63.0 \% IACS. The samples cast in argon have a lower porosity on the sample surface and electrical conductivity measured with Autosigma 3000 Eddy Current Tester has consequently higher values. Additionally, the electrical resistivity values were calculated. The values are comparable to the measurement results obtained with a custom-made measuring device. With an extrapolation estimation of results obtained with the four-point measuring method a comparison of both measuring method results was possible.

SEM using EDS analysis was made on the obtained samples. Figure 7 shows SEM images of the samples 997_z and 997_Ar. The microstructures of both are similar, but for sample 997_z some porosity and microcracks can be observed.

The presence of $\mathrm{Al}_{13} \mathrm{Fe}_{4}$ phase was confirmed and is shown in Figure 8. The $\mathrm{Al}_{9} \mathrm{Fe}_{2} \mathrm{Si}_{2}$ phase was not detected in our experimental samples.

\section{CONCLUSIONS}

The main research aim was to analyse the influence of the casting conditions on the electrical resistivity for castings made from Al-alloy 99.7. A calculation of the equilibrium phase diagram and the expected equilibrium proportion of the phases was performed. The Fe-eutectic $\left(\alpha-\mathrm{Al}+\mathrm{Al}_{13} \mathrm{Fe}_{4}\right)$ presence in the investigated samples microstructure was confirmed with SEM analysis. The casting conditions do not influence the temperature of the eutectic solidification. This was shown in all the experimental samples to be about $644{ }^{\circ} \mathrm{C}$. The electrical resistivity $\rho$ values are approximately $246 \mathrm{n} \Omega \mathrm{m}$ at the casting temperatures and at $20{ }^{\circ} \mathrm{C}$ about $30 \mathrm{n} \Omega \mathrm{m}$. The

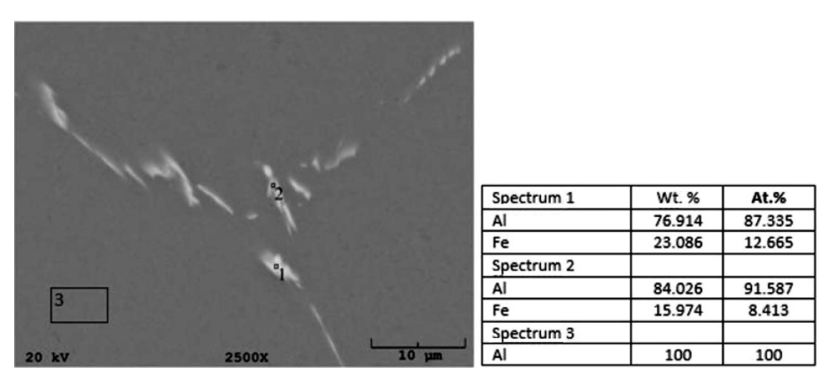

Figure 8: SEM images and EDS analysis of phases in sample 997_z

electrical resistivity results from the four-point measuring method and the eddy-current method are comparable. Sample 997_z cast in air had the lowest resistivity values obtained by the four-point measuring method, although it had the largest amount of impurities and porosity. It is believed that this was a consequence of the larger cross-section surface A, which was measured to be $6 \%$ more than on the other two samples.

\section{REFERENCES}

${ }^{1}$ J. S. Agapiou, Inertia welding for assembly of copper squirrel cages, Journal of Manufacturing Processes, 16 (2014), 276-283, doi:10.1016/j.jmapro.2013.09.009

${ }^{2}$ J. L. Kirtley, Jr., H. W. Beaty, Electric Motor Handbook, McGrawHill Book Company, 1998

${ }^{3}$ J. R. Davis, Aluminum and Aluminum Alloys, ASM international The Materials Information Society, 1994

${ }^{4}$ Properties and selection: Nonferrous Alloys and Special-Purpose Materials. ASM international - The Materials Information Society, 1990

${ }^{5}$ I. J. Polmear, Light Alloys, Metallurgy of the Light Metals $\left(3^{\text {rd }}\right.$ ed.), Butterworth-Heinemann, 1995

${ }^{6} \mathrm{~J}$. A. Taylor, Iron-containing intermetallic phases in Al-Si based casting alloys, Procedia Materials Science, 1 (2012), 19-33, doi:10.1016/j.mspro.2012.06.004

${ }^{7}$ H. Lopes de Moraes, J. R. de Oliveira, D. C. Romano Espinosa, J. A. Soares Tenório, Removal of iron from molten recycled aluminium through intermediate phase filtration, Materials Transactions 47 (2006), 1731-1736, doi:10.2320/matertrans.47.1731

${ }^{8}$ M. Torkar, B. Breskvar, M. Tandler, Đ. Mandrino, M. Doberšek, EPMA and HRAES Determination of complex inclusions in primary aluminium, Vacuum, 62 (2001), 379-385

${ }^{9}$ B. Farhoodi, R. Raiszadeh, M. Ghanaatian, Role of double oxide film defects in the formation of gas porosity in comercial purity and Sr-containing Al alloys, Journal of Materials Science \& Technology, 30 (2014), 154-162

${ }^{10}$ J. Campbell, Castings, Butterworth-Heinemann Ltd, 1991

${ }^{11}$ L. Zhao, Y. Pan, H. Liao, Q. Wang, Degassing of aluminum alloys during re-melting, Materials Letters, 66 (2012), 328-331, doi:10.1016/j.matlet.2011.09.012

${ }^{12}$ M. Petrič, Sprememba dimenzij in električne upornosti med strjevanjem litin iz sistema Al-Si, PhD thesis, Ljubljana, 2013

${ }^{13}$ X. Cui, Y. Wu, X. Liu, Q. Zhao, G. Zhang, Effects of grain refinement and boron treatment on electrical conductivity and mechanical properties of AA1070 aluminum, Materials and design, 86 (2015), 397-403, doi:10.1016/j.matdes.2015.06.149

${ }^{14}$ X. Cui, Y. Wu, G. Zhang, Y. Liu, X. Liu, Study on the improvement of electrical conductivity and mechanical properties of low alloying electrical aluminum alloys, Composites Part B, 110 (2017), 381-387, doi:10.1016/j.compositesb.2016.11.042 


\section{T. POŽENEL KOVAČIČ et al.: INFLUENCE OF DIFFERENT CASTING CONDITIONS AND ...}

${ }^{15}$ J. W. Gao, D. Shu, J. Wang, B. D. Sun, Effect of boron on removal of iron from aluminium melts, Materials Science and Technology, 25 (2009), 1462-6, doi:10.1179/174328408X382181

${ }^{16}$ R. Brandt, G. Neuer, Electrical resistivity and thermal conductivity of pure aluminum and aluminum alloys up to and above the melting temperature, International Journal of Thermophysics, 28 (2007), 1429-1446, doi:10.1007/s10765-006-0144-0

${ }^{17}$ W. K. Rhim, T. Ishikawa, Noncontact electrical resistivity measurement technique for molten metals, Review of scientific instruments, 69 (1998), 3628-3633, doi:10.1063/1.1149150
${ }^{18}$ G. Lohöfer, Electrical resistivity measurement of liquid metals, Measurement science and technology, 16 (2005), 417-425, doi:10.1088/0957-0233/16/2/012

${ }^{19}$ M. Petrič, S. Kastelic, P. Mrvar, Selection of electrodes for the "in situ" electrical resistivity measurements of molten aluminium, Journal of mining and metallurgy, Section B, Metallurgy, 49 (2013), 279-283, doi:10.2298/JMMB130118029P

${ }^{20}$ M. Vončina, T. Poženel, M. Petrič, P. Mrvar, J. Medved, Vpliv livarskih napak na električne lastnosti ulitka iz aluminija, Livarski vestnik, 64 (2017), 172-179 